\title{
EFEKTIFITAS BACKMASSAGE TERHADAP FATIGUE PADA PASIEN KANKER PAYUDARA YANG MENJALANI KEMOTERAPI
}

\section{THE EFFECTIVENESS OF BACK MASSAGE ON FATIGUE IN PATIENTS WITH BREAST CANCER UNDERGOING CHEMOTHERAPY}

\author{
Sapti Ayubbana \\ Akademi Keperawatan Dharma Wacana Metro
}

\begin{abstract}
ABSTRAK
Pasien kanker payudara yang menjalani kemoterapi dapat mengalami gangguan irama sirkandian berupa gangguan siklus tidur dan berakibat terjadinya fatigue. Penelitian ini bertujuan mengetahui efektifitas back massage terhadap fatigue pada pasien kanker payudara. Penelitian ini menggunakan quasi experimental pretestposttest group design, metode pengumpulan sampel secara purposive sampling. Sampel penelitian adalah 42 pasien kanker payudara yang menjalani kemoterapi dengan skor fatigue $\leq 30$. Pengukuran fatigue menggunakan instrumen Brief Fatigue Inventory (BFI). Hasil uji paired t testmenunjukan bahwa ada perbedaan yang signifikan antara BFI sebelum kemoterapi dengan setelah kemoterapi ( $p$ value $=0,000$ ) pada kelompok intervensi.
\end{abstract}

Kata kunci: back massage, BFI, fatigue, kanker payudara.

\begin{abstract}
Breast cancer patients undergoing chemotherapy may experience circadian rhythm disturbances such as sleep disturbance and fatigue. The aim of this study was to determine the effectiveness of back massage toward fatigue in breast cancer patients. A quasi experimental pretest-posttest group design with purposive sampling method was used. The study involved 42 breast cancer patients undergoing chemotherapy with fatigue score $\leq 30$. Fatigue was measured by using Brief Fatigue Inventory (BFI) instrument. The paired t test results showed BFI significant difference between before and after chemotherapy ( $\mathrm{p}$ value $=0.000$ ) in the intervention goup.
\end{abstract}

Keywords: back massage, breast cancer, BFI, fatigue 


\section{PENDAHULUAN}

Kanker payudara merupakan kanker yang sering terjadi pada wanita dan menjadi salah satu penyebab kematian di dunia. Berdasarkan International Agency for Research on Cancer (IARC) tahun 2012 insiden kanker payudara menduduki posisi pertama jenis kanker yang ditemui pada wanita baik tingkat dunia, asia, dan di Indonesia. Insiden kanker payudara pada wanita di dunia tahun 2012 sebesar $1.671 .149(25,1 \%)$ dengan angka mortalitas sebesar $521.907 \quad(14,7 \%)^{11}$. Insiden kanker payudara pada wanita di Asia tahun 2012 sebesar 650.983 (21,2 \%) dengan angka mortalitas sebesar 231.013 $(12,8 \%)$ dan di Indonesia insiden kanker payudara sebesar 48.998 (30,5\%) dengan angka mortalitas sebesar $19.750(30,5 \%)^{11}$.

Kanker payudara merupakan penyakit sel dimana terjadi perubahan pengaturan siklus sel menjadi tidak terkendali ${ }^{\mathbf{0}}$. Kanker dapat terjadi di payudara dan menyebar di berbagai organ tubuh manusia. Kanker payudara memerlukan modalitas pengobatan untuk tujuan yang dapat dicapai. Modalitas pengobatan dapat sebagai penyembuhan, menghambat pertumbuhan sel-selkanker, atauhanya menghilangkan gejala yang ditimbulkan oleh proses penyakit kanker ${ }^{32}$.
Modalitas pengobatan kanker payudara terdiri atas operasi, radioterapi, bioterapi, kemoterapi, dan terapi hormonal $^{1,10}$. Kemoterapi memiliki kelebihan dibanding terapi lainnya karena obat kemoterapi mampu berdampak secara sistemik merusak sel kanker yang telah menyebar dari tempat asalnya ${ }^{2^{\mathbf{o}}}$. Obat kemoterapi bekerja mengganggu reproduksi sel kanker secara langsung atau tidak langsung, sehingga sel-sel kanker dapat terkontrol dan tereradikasi ${ }^{7}$.

Pemberian kemoterapi menggunakan kombinasi golongan obat dan diberikan dalam beberapa kali siklus. Setiap siklus terdiri beberapa kali pemberian kemoterapi ${ }^{10}$. Pemberian kemoterapi dapat merubah irama sirkadian pasien 16,17,24,26,28, Irama sirkadian adalah regulasi proses internal tubuh yang diatur oleh jam biologis tubuh, salah satunya adalah siklus tidur bangun ${ }^{7,16,26,31}$. Pasien kanker selama kemoterapi mengalami ganguan irama sirkadian berkaitan dengan gangguan tidur dan sering terbangun ${ }^{7,26,31}$. Beberapa gangguan tidur selama kemoterapi adalah seringnya terbangun malam (49\%-56\%), ketidakmampuan untuk tidur dalam waktu 30 menit (50\%- $73 \%)$ dan terbangun awal $(49 \%-65 \%)^{22}$. Perubahan siklus tidur bangun yang dirasakan pasien selama 
pemberian kemoterapi dapat menyebabkan

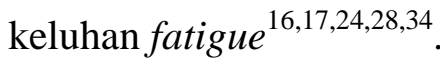

Fatigue merupakan perasaan subjektif atas kelelahan fisik, kognitif, emosional berkaitan dengan kanker atau pengobatan kanker dan kelelahan yang dirasakan tidak sebanding dengan aktifitas yang dilakukan ${ }^{19}$. Individu menggambarkan fatigue menggunakan kata-kata yang berbeda, termasuk lelah, kekurangan energi, lemah, lesu, letih, bosan, tidak bisa tidur, atau memiliki gangguan tidur ${ }^{17}$.

Liu et al (2013) menyatakan penelitian yang dilakukan pada 148 pasien kanker payudara stadium I-III mendapatkan 4 siklus kemoterapi adjuvant atau neoadjuvan mengalami fatigue. Hasil penelitian didapatkan bahwa fatigue pasien kanker payudara lebih tinggi pada saat siklus keempat kemoterapi dibandingkan dengan prakemoterapi $(\mathrm{p}<0,05)$. Peningkatan skor total fatigue berkaitan dengan ganggguan irama sirkadian $(p<0.006)$.

Keluhan fatigue akan menimbulkan ketidaknyamanan pasien. Menurut teori comfort yang disampaikan oleh Kolcaba, intervensi awal dari pelayanan keperawatan adalah kenyamanan ${ }^{4}$. Salah satu intervensi yang dapat membuat klien merasa nyaman adalah dengan tindakan massage ${ }^{4}$. Massage adalah sentuhan dengan memanipulasi jaringan lunak untuk mempromosikan kenyamanan dan penyembuhan ${ }^{8}$. Back massage merupakan intervensi mandiri keperawatan dan menunjukan caringnya perawat pada pasien. Tindakan back massage mudah dilakukan dan aman ${ }^{18}$.Massage sudah lama dikenal dan disukai oleh masyarakat Indonesia.

Tindakan massage meningkatkan sirkulasi darah, menurunkan ketegangan otot, memberikan relaksasi ${ }^{13,} 35$, meningkatkan suasana hati ${ }^{15}$, peningkatan hormon endorphin ${ }^{35}$, meningkatkan aktivitas neurotrasmitter serotonin dan membantu klien meningkatkan istirahat dan tidur $^{30}$.

Berdasarkan uraian yang telah dijabarkan diatas, penelitian ingin mengidentifikasi efektifitas back massage terhadap fatigue pada pasien kanker payudara yang menjalani kemoterapi. Penelitian ini bertujuan untuk untuk mengetahui efektifitas back massage pada pasien kanker payudara yang menjalani kemoterapi dan mengetahhui faktor confonding yang mempengaruhi intervensi yang dilakukan.

\section{METODE}

Desain yang digunakan adalah quasi eksperimental dengan pendekatan pre test post test group design. Penelitian ini 
dilakukan di Ruang Mawar RSUD Dr. H. Abdul Moeloek Provinsi Lampung dengan melibatkan sebanyak 42 pasien kanker payudara yang menjalani kemoterapi yang memenuhi kriteria inklusi. Alat pengumpul data dalam penelitian ini menggunakan kuesioner BFI yang telah diuji validitas dan reliabilitasnya. Data yang didapat dianalisis dengan menggunakan spss versi 21 secara univariate, bivariate (paired $t$ test)dan multivariat (regresi linear).

\section{HASIL}

Data karakteristik responden yang didapat adalah sebagai berikut sebagian rerata usia responden berusia 46,67 tahun , stadium kanker respodensebagian besar stadium $3(85,7 \%)$, obat kemoterapi yang digunakan respondensebagian besar menggunakan regimen CAF (85,7\%), siklus kemoterapi responden sebagian besar responden siklus I $(85,7 \%)$, kadar hemoglobin sebagian besar responden bernilai $11,75 \mathrm{gr} / \mathrm{dl}$, status nutrisi sebagian kecil responden mengalami malnutrisi $(9,5$ $\%$ dan sebagian besar responden mengalami gangguan tidur $(85,7 \%)$. Analisa bivariat fatigue sebelum dan sesudah perlakuan dapat dilihat pada tabel berikut ini :
Tabel 1.

\section{Analisis perbedaan rerata BFI sebelum \& sesudah diberikan perlakuan pada kelompok intervensi}

\begin{tabular}{lcccc}
\hline Variabel & Mean & SD & SE & $\begin{array}{c}p \\
\text { value }\end{array}$ \\
\hline Kelompok & & & & \\
a.sebelum & 48,90 & 11,229 & 2,450 & $0,000^{*}$ \\
b. sesudah & 36,67 & 10,461 & 2,283 & \\
\hline & $*$ value $<0,05$ signifikan &
\end{tabular}

Tabel 1. Menunjukkan bahwa berdasarkan analisis dengan menggunakan uji parametrik yaitu paired $t$ test menunjukan bahwa ada perbedaan yang signifikan antara BFI sebelum kemoterapi dengan setelah kemoterapi ( $p$ value $=$ 0,000) pada kelompok intervensi.

Berdasarkan uji bivariat antara variabel confounding dengan fatigue menunjukkan hasil bahwa variabel status nutrisi pada kelompok intervensi mempunyai hubungan yang bermakna dengan fatigue $(p$ value $=0,031)$ dengan kekuatan korelasi sedang $(\mathrm{r}=0,471)$. Begitu juga variabel nyeri pada kelompok intervensi mempunyai hubungan yang bermakna dengan fatigue ( $p$ value $<0,05$ ) dengan kekuatan korelasi sedang $(\mathrm{r}=0,40$ 0,599). Sedangkan variabel stadium kanker, obat kemoterapi, siklus kemoterapi, kadar hemoglobin, gangguan tidur pada kelompok intervensi dan status nutrisi kelompok intervensi menunjukkan bahwa tidak terdapat hubungan yang bermakna. 
Hasil uji multivariat regresi linear kelompok intervensi adalah sebagai berikut :

Tabel 2

Hasil analisis multivariat regresi linear pada kelompok intervensi di RSDU Dr. H. Abdul Moeloek Provinsi Lampung

\begin{tabular}{lccl}
\hline \multicolumn{1}{c}{ Variabel } & Koefisien & $\begin{array}{c}\text { Koefisien } \\
\text { korelasi }\end{array}$ & $\begin{array}{l}p \\
\text { value }\end{array}$ \\
\hline $\begin{array}{l}\text { Obat } \\
\text { kemoterapi }\end{array}$ & $-14,325$ & $-0,491$ & 0,398 \\
$\begin{array}{l}\text { Siklus } \\
\text { kemoterapi }\end{array}$ & 13,700 & 0,818 & 0,155 \\
$\begin{array}{l}\text { Status } \\
\text { nutrisi }\end{array}$ & 18,275 & 0,525 & $0,05^{*}$ \\
$\begin{array}{l}\text { Nyeri } \\
\text { Konstanta }\end{array}$ & 5,400 & 0,362 & 0,063 \\
\hline
\end{tabular}

Tabel 2 menunjukkan bahwa hasil analisis multivariat regresi linear pada kelompok intervensi didapatkan bahwa semua variabel confounding (obat kemoterapi, siklus kemoterapi, status nutrisi, dan nyeri ) mempunyai $p$ value> 0,05 sehingga pemodelan tidak dapat dibentuk. Artinya bahwa tidak ditemukan pemodelan yang sesuai untuk menggambarkan faktor-faktor yang berhubungan dengan variabel dependen. Sehingga dapat disimpulkan bahwa tidak ada informasi dari variabel confounding untuk memperkirakan tingkat fatigue terhadap fatigue pada responden kelompok intervensi .

\section{PEMBAHASAN}

Hasil analisis paired $t$ test menunjukan bahwa ada perbedaan yang signifikan antara BFI sebelum kemoterapi dengan setelah kemoterapi ( $p$ value $=$ 0,000) pada kelompok intervensi.Artinya intervensi efektif dalam menurunkan fatigue pada pasien kanker payudara yang menjalani kemoterapi. Dengan kata lain bahwa back massage yang diberikan sebelum dan sesudah kemoterapi secara signifikan mengurangi fatigue dalam proses kemoterapi.

\section{Massage dapat memberikan efek} biomekanik, efekfisiologi, efek neurologi dan psikologi ${ }^{29,35}$. Tekanan mekanik dan gesekan pada daerah kulit dan otot dapat meningkatkan pemanasan lokal, meningkatkan vasodilatasi pembuluh darah sehingga meningkatkan sirkulasi darah, transportasi oksigen ,sehingga meningkatkan metabolisme jaringan. Efek psikologis adalah memberikan peningkatan hubungan tubuh dan mind sehingga dapat meningkatkan relaksasi ${ }^{35}$.

$$
\text { Jaringan tubuh dipersarafi oleh }
$$
mechanoreceptors dengan perjalanan dari saraf perifer sampai medula spinalis ke neorokorteks. Stimulus kemudian diintresprestasikan dan didistribusikan melalui korteks, otak tengah dan lower brain. Massage memberikan stimulus taktil 
jaringan tubuh menghasilkan relaksasi dengan respon neurohormonal berupa menurunkan kortisol, meningkatkan melatonin dan meningkatkan serotonin. Kortison, melatonin dan serotonin adalah hormon yang memberikan respon relaksasi dan tidur (Harris, 2009). Menurut Sturgeon et al (2009) menyatakan bahwa massage dapat meningkatkan kualitas hidup dan tidur. Tidur berkualitas terdiri dari tidur NREM dan REM dapat menyimpan energi selama tidur, berkontribusi dalam pemulihan fisik dan psikologis, memperbaiki proses biologi secara rutin ${ }^{25}$, menjaga mental dan mood ${ }^{7}$.

Robinson \& Smith (2016) menyatakan bahwa penelitian pada 58 pasien yang sedang menjalani kemoterapi. Massage yang diberikan selama 20 menit. Hasil penelitian didapatkan bahwa secara signifikan dapat menurunkan nyeri ( $\mathrm{p}<$ 0,002), fatigue $(\mathrm{p}<0,000)$ dan kecemasan $(\mathrm{p}<0,000)$ dibandingkan dengan sebelum massage. Skor rerata fatigue sebelum massage 3,88 dan menurun menjadi 3,04 pada saat setelah massage. Perbedaan skor rerata fatigue pada saat sebelum massage dan setelah massage adalah $0,84(\mathrm{t}=3,89$, $\mathrm{p}<0,000)$.

Hasil penelitian ini menunjukan bahwa variabel status nutrisi pada kelompok intervensi mempunyai hubungan yang bermakna dengan fatigue ( $p$ value $<$ 0,05). Penelitian ini menunjukkan bahwa sebagian kecil responden menunjukkan malnutrisi pada kelompok intervensi $(9,5$ $\%)$ mengalami fatigue. Hal ini tidak relevan dengan hasil penelitian sebelumnya yang menyatakan bahwa pasien kanker yang menerima kemoterapi memiliki resiko malnutrisi tinggi akibat penyakit dan pengobatannya. Terdapat $40-80 \%$ pasien kanker mengalami berbagai kekurangan gizi $^{27}$. Bozzetti (2009) menyatakan bahwa pasien yang menjalani kemoterapi mengalami penurunan $\mathrm{BB}>10 \%$.

Mekanisme terjadinya malnutrisi akibat ketidakmampuan tubuh untuk mendapatkan nutrisi yang cukup akibat efek samping kanker dan pengobatan. Sel kanker tumbuh dan berkembang secara tidak terkendali dalam tubuh dan memerlukan nutrisi untuk tumbuh dan berkembang ${ }^{7}$. Berat tubuh sangat bervariasi diantara individu. Ketika menghadapi ketidakcukupan pemasukan energi melalui makanan dalam waktu yang panjang, tubuh menguraikan protein otot untuk memenuhi kebutuhan pengeluaran energi ${ }^{31}$. Dampak yang ditimbulkan dari defisit suplai nutrisi yaitu penipisan jaringan adiposa, hilangnya masa otot dan fatigue. Dampak malnutrisi ini tercemin dari menurunnya berat badan ${ }^{7}$. Sebaliknya 
bila pemasukan total energi melebihi kebutuhan tubuh, kelebihan energi tersebut akan disimpan sebagai trigliserida dijaringan lemak. Hal ini menyebabkan peningkatan berat badan. Asumsi peneliti berdasarkan analisis univariat didapatkan bahwa penurunan berat badan selama 6 bulan terakhir menunjukkan bahwa penurunan $>5 \mathrm{~kg}$ pada kelompok intervensi I $(38,46 \%)$ dan kelompok intervensi II $(11,76 \%)$. Hal ini menunjukkan bahwa penggunaan massa tubuh untuk proses menghasilkan energi karena asupan nutrisi yang kurang.

Hasil penelitian ini menjelaskan bahwa terdapat hubungan yang bermakna antara nyeri dengan fatigue ( $p$ value $<0,05$ ) pada kelompok intervensi. Penelitian ini menunjukkan bahwa sebagian skala nyeri responden adalah sedang (52,4 \%) mengalami fatigue. Hal ini sejalan dengan penelitian yang menyatakan bahwa terhadap hubungan nyeri terhadap fatigue $(p \text { value }<0,000)^{9}$.

Massa tumor yang berkembang menjadi besar dapat menekan saraf, tulang dan organ lainnya yang terdapat disekitar tumor dapat menyebabkan keluhan nyeri. Nyeri berawal dari pengeluaran substansi seperti histamin, bradikinin, prostagladin dan substansi P. Pengeluaran zat-zat tersebut merupakan stimulus untuk memulai transmisi neural yang berkaitan dengan nyeri ${ }^{3,25}$. Stimulus nyeri mengaktifkan bagian sistem limbik untuk memproses emosi terhadap nyeri yakni memperburuk atau menghilangkan nyeri. Nyeri yang dirasakan individu merupakan kejadian menekan atau stress ${ }^{25}$. Berdasarkan teori yang relevan menyatakan bahwa hipotalamus menerima masukan mengenai kondisi stress fisik dan emosi dari bagian otak dan reseptor di seluruh tubuh. Hipotalamus memberikan respon secara langsung mengaktifkan sistem saraf simpatis, mengeluarkan corticotropin releasing hormone ( $\mathrm{CRH})$ untuk merangsang adrenocorticotropic hormone (ACTH) dan kortison dengan tujuan memobilisasi simpanan energi dan bahan baku metabolik untuk digunakan sesuai kebutuhan ${ }^{31}$.

\section{SIMPULAN}

Pemberian back massagese belum dan sesudah kemoterapi secara signifikan mengurangi fatigue dalam proses kemoterapi. Penurunan fatigue hasil dari pemberian intervensi back massage dan tidak dipengaruhi faktor counfonding (stadium kanker, obatkemoterapi, sikluskemoterapi, status nutrisi, kadar hemoglobin, nyeri, dangangguantidur). 
Hasil penelitian ini menunjukkan bahwa pemberian back massage efektif menangani fatigue sehingga dapat menjadi salah satu pilihan intervensi dalam menangani fatigue pada pasien kanker yang menjalani kemoterapi.

\section{SARAN}

Penelitian lanjutan mengenai intervensi back massage terhadap fatigue perlu dilanjutkan dengan menggunakan design penelitian Randomized Control Trial (RCT) dengan memperbanyak jumlah responden dan tempat penelitian. Hal ini dilakukan agar semua sampel terpilih memiliki karakteristik yang homogen untuk mengurangi bias dalam hasil penelitian.

\section{DAFTAR PUSTAKA}

1. American Cancer Society. (2016). Cancer Facts \& Figures 2016. Atlanta: American Cancer Society

2. American Cancer Society. Breast Cancer Facts \& Figures 2015-2016. Atlanta: American Cancer Society

3. American Medical Association. Pain management: pathophysiology of pain and pain assessment. from : http://www.ama-meonline.com/ pain_mgmt/module01/index.htm.

4. Alligood, M.R \&Marriner Tomey, A. (2014). Nursing theorist and their work. Sixth ed,.St.Louis : Mosby

5. Barsevick, A., Frost, M., Zwinderman, A., Hall, P., Halyard, M. (2010). I'am so tired : biological and genetic machanisms of cancer-related fatigue. Qual LifeRes.19:1419-1427. doi.org/10.1007/s11136-010-9757-7

6. Beck, S. L., Berger, A. M., Barsevick, A. M., Wong, B., Stewart, K. A., \& Dudley, W. N. (2010). Sleep quality after initial chemotherapy for breast cancer. Support Care Cancer, 18, 679689. Bulechek, G.M., Butcher, H.K., Dochterman, J.M., Wagner, C.M. (2013). Nursing Interventions classification (NIC). St.Louis : Elsevier Mosby

7. Black Joyme M \& Hawk. Jane H (2014). Keperawatan Medikal Bedah : Manajemen Klinik Campos, M.P., Hassan, B.J., Riechelmann, R., Giglio, A. (2011). Cancer-related fatigue: a review. Rev Assoc Med Bras, 57(2), 206-214

8. Chen, W., Liu, G.,Yeh, S.,Chiang, M., Fu, M., and Hsieh, Y. (2013). Effect of Back Massage Intervention on Anxiety, Comfort, and Physiologic Responses in Patients with Congestive Heart Failure.

The Journal of Alternative and Complementary Medicine, 19(5), 464470.

https://doi.org/10.1089/acm.2011.0873

9. Claudia, A., Cavalli, G., Urbanetz, A. A., Carvalho, D. S. De, Mara, E., \& Pereira, C. (2012). Fatigue after treatment in breast cancer survivors : prevalence, determinants and impact on health-related quality of life. Support Care Cancer, 1901-1909. https://doi.org/10.1007/s00520-0111293-7

10. Desen, Wan. (2011). Buku Ajar onkologi klinis. Jakarta : Balai penerbit FKUI 
11. Interational Agency for Research on Cancer(IARC) / WHO. (2012). GLOBOCAN 2012: Estimated cancer incidence, mortality, and prevalence worldwide in 2012.

12. Karadag, E., Samancioglu, S., Ozden, D., \& Bakir, E. (2015). Effects of aromatherapy on sleep quality and anxiety of patients. British Association of Critical Care Nurses.http://doi.org/10.1111/nicc.1219 8

13. Karagozoglu, S. \&Kahve, E. (2013). Effects of back massage on chemotherapy-related fatigue and anxiety: Supportive care and therapeutic touch in cancer nursing. AppliedNursingResearch 26 (2013) 210217. doi.org/10.1016/j.apnr.2013.07.002

14. Lillehei, A. S. (2014). Effect of lavender aromatherapy via inhalation and sleep hygiene on sleep in college students with self-reported sleep issues. Dissertation. The Faculty of The University Of Minnesota

15. Listing et al. (2009). Massage therapy reduces physical discomfort and improves mood disturbances in women with breast cancer. Psycho-Oncology, 18 :1290-1299. http://doi.org/10.1002/pon.1508

16. Liu et al.(2013). Fatigue and circadian activity rhythms in breast cancer patients before and after chemotherapy: a controlled study.Fatigue: Biomedicine, Health \& Behavior, 1:1-2,12-26. doi : 10.1080/21641846.2012.741782

17. Miaskowski, C. \& Aouizerat, B.A. (2014). Contribution of sleep disturbance to cancer fatigue.Dalam Redline, $\mathrm{S}$ and N.A. Berger, N.A
(eds.),Impact of Sleep and Sleep

Disturbances on Obesity 169 and Cancer, Energy Balance and Cancer 8. Business Media New York. doi : 10.1007/978-1-4614-9527-7_9

18. Miladinia, M., Baraz, S., Shariati, A., \& Malehi, A. S. (2016). Effects of Slow-Stroke Back Massage on Symptom Cluster in Adult Patients With Acute Leukemia: Supportive Care in Cancer Nursing. Cancer Nursing, O(0), 1-8. https://doi.org/10.1097/NCC.000000000 0000353

19. National Comprehensive Cancer Network (NCCN).(2014). NCCN clinical practice guidelines in oncology(NCCN Guidenlines) :cancerrelated fatigue I.2014. NCCN.org

20. Otto, Shirley.E. (2005). Bukusakukeperawatanonkologi. Jakarta : EGC

21. Palesh et al. (2010).Prevalence, demographics, and psychological associations of sleep disruption in patients with cancer: University of Rochester Cancer Center-Community Clinical Oncology Program.Journal of Clinical Oncology.28 (2) doi: 10.1200/JCO.2009.22.5011

22. Palesh, O., Peppone, L., Innominato, P. F., Janelsins, M., Jeong, M., Sprod, L., Savard, J., ... Mustian, K. (2012). Prevalence , putative mechanisms, and current management of sleep problems during chemotherapy for cancer. Nature and Science of Sleep, 4, 151-162. doi : 10.2147/NSS.S18895

23. Payne, J. K. (2004). A Neuroendocrine-Based Regulatory Fatigue Model. Biological Research for Nursing,6:141-150. 
http://doi.org/10.1177/10998004042682 $\underline{80}$

24. Payne, J.K. (2011). Altered circadian rhythms and cancer- related fatigue outcomes. Integrative Cancer Therapies .10 (3): 221- 233. doi: 10.1177/1534735410392581

25. Potter, P.A., \& Perry, A.G. (2006). Buku ajar fundamental keperawatan. Jakarta : EGC

26. Ryan, J.L.,et al.(2007). Mechanisms of Cancer-Related Fatigue.The Oncologist : 12(1): 22-34.doi: 10.1634/theoncologist.12-S1-22

27. Sa'nchez-Lara, K., Ugalde-morales, E., Motola-kuba, D., Green, D., \& Sa, K. (2013). Gastrointestinal symptoms and weight loss in cancer patients receiving chemotherapy, 894-897. https://doi.org/10.1017/S000711451200 2073

28. Savard, J., Liu, L., Natarajan, L., Rissling, M. B., Neikrug, A. B., He, F., ... Ancoli-israel, S. (2009). Breast cancer patients have progressively impaired sleep-wake activity rhythms during chemotherapy. Sleep, 32(9), 1-6.

29. Salvo, S.G. (2012). Massage therapy : principles and practice. Canada : Elseiver Saunders

30. Shinde, M. B., \& Anjum, S. (2014). Effectiveness of Slow Back Massage on Quality of Sleep among ICU Patent' s. International Journal of Science and Research (IJSR), 3(3), 292-298.

31. Sherwood, Lauralee. (2014). Fisiologimanusia: dariselkesistem; Ed.8. Jakarta : EGC

32. Smeltzer, S.C \& Bare, Brenda. G. (2008). Buku ajar keperawatanmedikalbedah Brunner \&Suddarth. Jakarta : EGC
33. Sturgeon, M., Wetta-hall, R., Hart, T., C, Good, M., \& Dakhil, S. (2009). Effects of therapeutic massage on the quality of life among patients with breast cancer during treatment. The Journal of Alternative and Complementary Medicine, 15(4), 373-380. http://doi.org/10.1089/acm.2008.0399

34. Wang, X.S.(2008). Pathophysiology of cancer-related fatigue. Clinical Journal of Oncology Nursing, 12(5), 11-12. doi: 10.1188/08.CJON.S2.11-20

35. Weerapong, P., Hume, P. A., \& Kolt, G. S. (2005). The Mechanisms of Massage and Effects on Performance, Muscle Recovery and Injury Prevention. Sports Med, 35(3), 235-256. 